\title{
Thiorhodococcus mannitoliphagus sp. nov., a purple sulfur bacterium from the White Sea
}

Correspondence

Johannes F. Imhoff jimhoff@ifm-geomar.de

\author{
Sandra Rabold, ${ }^{1}$ Vladimir M. Gorlenko ${ }^{2}$ and Johannes F. Imhoff ${ }^{1}$ \\ 'Leibniz Institut für Meereswissenschaften IFM-GEOMAR, Düsternbrooker Weg 20, \\ D-24105 Kiel, Germany \\ ${ }^{2}$ Winogradsky Institute of Microbiology, Russian Academy of Sciences, pr. 60-letiya Oktyabrya \\ 7, k. 2, Moscow, 117312, Russia
}

Along marine shorelines, purple sulfur bacteria are often found in anoxic sediments and in shallow waters of separated water bodies, such as coastal lagoons. Prerequisites for their development are the presence of both reduced sulfur compounds and solar light. Because these factors naturally form counter-current gradients, growth of phototrophic bacteria is often found within thin layers along the appropriate borderline. These special conditions arise for example regularly in estuaries, where so-called microbial mats develop that exhibit very high population densities in thin coloured layers (van Gemerden \& Mas, 1995). Due to the transient situation in estuaries between freshwater and marine salt concentrations, both marine and freshwater species of phototrophic bacteria can be found (Gorlenko et al., 1985; Puchkova et al., 2000).

Purple sulfur bacteria belong to the Gammaproteobacteria and comprise the two families Chromatiaceae and Ectothiorhodospiraceae (Imhoff, 1984). These families differ in respect to the deposition of sulfur globules formed during the oxidation of reduced sulfur compounds: members of the Chromatiaceae deposit the globules intracellularly, whereas representatives of the Ectothiorhodospiraceae deposit them

The GenBank/EMBL/DDBJ accession number for the 16S rRNA gene sequence of strain $\mathrm{WS}^{\top}$ is AJ971090. extracellularly. Phenotypic characteristics like cell shape or pigment composition were traditional criteria to distinguish bacterial species (Winogradsky, 1888; Pfennig \& Trüper, 1974). Today, the analysis of $16 \mathrm{~S}$ rRNA gene nucleotide sequences is an additional important tool for species differentiation (Imhoff \& Süling, 1996; Imhoff et al., 1998a, b). It is particularly valuable if combined with phenotypic properties to allow a detailed characterization of new bacterial isolates.

Strain $\mathrm{WS}^{\mathrm{T}}$ was isolated from material taken from a microbial mat in an estuary of the Nilma river, on the White Sea coast of north-western Russia. In this area, regions of shallow supralittoral beach, which are covered only periodically by brackish water, exhibit the development of natural microbial mats. In addition to cells similar in morphology to strain $\mathrm{WS}^{\mathrm{T}}$, the purple sulfur bacteria Thiocapsa roseopersicina, Thiocapsa purpurea, Thiocapsa litoralis, Thiorhodovibrio winogradskyi and Allochromatium vinosum and the green sulfur bacterium Prosthecochloris aestuarii were found in these microbial mats (Gorlenko et al., 1985; Puchkova et al., 2000).

The 16S rRNA gene sequence of strain $\mathrm{WS}^{\mathrm{T}}$ exhibited clear affiliation to the genus Thiorhodococcus. The genus Thiorhodococcus, with the type species Thiorhodococcus minor (Guyoneaud et al., 1997; Imhoff et al., 1998b), is one of 
the genera belonging to the family Chromatiaceae. Important morphological features such as coccoid cells are common to the genera Thiorhodococcus, Thiocystis, Thiocapsa, Thiococcus, Thiohalocapsa, Thiolamprovum, Lamprocystis, Thioalkalicoccus and Thioflavicoccus (Guyoneaud et al., 1997; Imhoff, 2001; Imhoff \& Pfennig, 2001; Bryantseva et al., 2000). Both the sequence distance and a number of differences in phenotypic properties differentiate the novel bacterium from known Thiorhodococcus species, which consequently necessitates the description of a novel species.

For isolation of strain $\mathrm{WS}^{\mathrm{T}}$, cultivation of the pure culture and for growth experiments, Pfennig's medium was used (Pfennig \& Trüper, 1992) $\left(\mathrm{l}^{-1}\right): 0.34 \mathrm{~g} \mathrm{KH}_{2} \mathrm{PO}_{4}, 0.34 \mathrm{~g}$ $\mathrm{NH}_{4} \mathrm{Cl}, 0.5 \mathrm{~g} \mathrm{MgSO}_{4} .7 \mathrm{H}_{2} \mathrm{O}, 0.05 \mathrm{~g} \mathrm{CaCl}_{2} \cdot 2 \mathrm{H}_{2} \mathrm{O}, 0.34 \mathrm{~g} \mathrm{KCl}$, $1 \mathrm{ml} \mathrm{SLA}$ (Imhoff, 1992), $20 \mu \mathrm{g}$ vitamin $\mathrm{B}_{12}, 1 \cdot 5 \mathrm{~g} \mathrm{NaHCO}_{3}$, $0.4 \mathrm{~g} \mathrm{Na}_{2} \mathrm{~S} .7-9 \mathrm{H}_{2} \mathrm{O}, 0.5 \mathrm{~g} \mathrm{Na}_{2} \mathrm{~S}_{3} \mathrm{O}_{3} .5 \mathrm{H}_{2} \mathrm{O}, 15 \mathrm{~g} \mathrm{NaCl}, 2.5 \mathrm{~g}$ $\mathrm{MgCl}_{2} \cdot 6 \mathrm{H}_{2} \mathrm{O}$. The $\mathrm{pH}$ was adjusted to $7 \cdot 5$.

Pure cultures were obtained by repeated application of the deep-agar dilution method (Pfennig \& Trüper, 1992). Agar tubes were incubated at $30^{\circ} \mathrm{C}$ under a light-dark cycle $(16 \mathrm{~h}$ $500 \mathrm{~lx}$ light, $8 \mathrm{~h}$ dark) using tungsten lamps. Purity of the isolate was checked by both microscopy and growth tests in deep-agar or liquid media supplemented with $5 \mathrm{mM}$ acetate and incubated in the dark. Pure cultures were grown in $100 \mathrm{ml}$ screw-capped bottles filled with synthetic medium, incubated at $2000 \mathrm{~lx}\left(42 \mu \mathrm{mol}\right.$ quanta $\left.\mathrm{m}^{-2} \mathrm{~s}^{-1}\right)$ at $25^{\circ} \mathrm{C}$. Repeated addition of neutralized sulfide solution was used to obtain high cell yields (Siefert \& Pfennig, 1984). Stock cultures were stored at $5{ }^{\circ} \mathrm{C}$ in the dark. Growth was followed photometrically by measuring optical density at $650 \mathrm{~nm}$ (UV/VIS spectrophotometer Lambda 2; Perkin Elmer).

Microscopic observations of cells of strain $\mathrm{WS}^{\mathrm{T}}$ were done using a phase-contrast microscope (Axiophot; Zeiss). The fine structure of the cells was studied by electron microscopy after fixation of a cell pellet by the method of Ryter \& Kellenberger (1958) and ultrathin sectioning of the cells. Observations were made with a JEOL 100 electron microscope.

The absorption spectrum of the living cells was measured after suspension of a cell pellet in $50 \%$ glycerol using a UV/ VIS spectrophotometer Lambda 2 (Perkin Elmer).

Growth tests were performed using Pfennig's medium described above aliquotted into $20 \mathrm{ml}$ screw-capped tubes. According to the test conditions, the $\mathrm{pH}$ and the salt concentration were varied. Different salt concentrations were obtained using a concentrated salt solution containing $\left(\mathrm{l}^{-1}\right) 294 \mathrm{~g} \mathrm{NaCl}$ and $47 \mathrm{~g} \mathrm{MgCl}_{2} \cdot 6 \mathrm{H}_{2} \mathrm{O}$ (N. Pfennig, personal communication). The optimal $\mathrm{pH}$ was determined first and experiments to determine the optimal salt concentration were performed at optimal $\mathrm{pH}$. Additional tests were performed at optimal $\mathrm{pH}$ and salt concentration. For nutritional experiments, several electron donors and carbon sources were tested, according to the recommended standards for the description of novel species (Imhoff \&
Caumette, 2004), with the final concentrations indicated in Table 1 . The tubes were inoculated with a volume of $5 \%$ preculture and incubated at $25^{\circ} \mathrm{C}$ and $2000 \mathrm{~lx}(42 \mu \mathrm{mol}$ quanta $\mathrm{s}^{-1} \mathrm{~m}^{-2}$ ) for 5 days. For each experiment, three serial repetitions were carried out. Bacterial growth was measured as $\mathrm{OD}_{650}$ as described above. The measurements were performed using sterile Pfennig's medium as a blank and reference sample. Bacterial growth in standard Pfennig's medium incubated under exactly the same conditions was used as control.

To determine the possibilities of chemotrophic growth in the dark and growth in the presence of oxygen, tubes with $3 \mathrm{ml}$ soft agar $(1.8 \%)$ were mixed with $6 \mathrm{ml}$ medium, inoculated with $1 \mathrm{ml}$ well-grown liquid culture and incubated with a headspace of air under both light $(2000 \mathrm{~lx}$, $42 \mu \mathrm{mol}$ quanta $\left.{ }^{-1} \mathrm{~m}^{-2}\right)$ and dark conditions at $25^{\circ} \mathrm{C}$. The requirement for vitamin $B_{12}$ as a growth factor was tested in medium free of vitamins and growth factors.

DNA from pure cultures was extracted using the QIAamp DNA Mini kit (Qiagen). The 16S rRNA gene was amplified using eubacterial primers $5^{\prime}$-27F (5'-AGTTTGATCCTGGCTCAG-3') and $3^{\prime}-1492 \mathrm{R}\left(5^{\prime}\right.$-GGTTACCTTGTTACGACTT-3') and puReTaq Ready-To-Go PCR beads (Amersham Biosciences). The QIAquick PCR purification kit (Qiagen) was used to purify the PCR products. Sequence data were obtained using the method of Sanger et al. (1977). Automated sequence determination was performed using an ABI PRISM 310 Genetic Analyzer (Applied Biosystems). The complete sequence was assembled from several fragments by using the software SeqMan II 4.03 (DNASTAR) (Swindell \& Plasterer, 1997).

For phylogenetic classification, alignments including various sequences from databases were created with the aid of the software program CLUSTAL X 1.83 (Thompson et al., 1997). PHYLIP version 3.63 (Felsenstein, 2004) was used to create a distance matrix (based on the maximum-likelihood algorithm) and a phylogenetic tree was constructed with PHYML. For the determination of DNA base composition, the DNA was isolated by applying the method of Marmur (1961). The DNA base composition was determined according to Owen et al. (1969).

Under optimal growth conditions in the medium described above, single cells of strain $\mathrm{WS}^{\mathrm{T}}$ exhibit a coccoid morphology. During binary fission, diplococci are formed. The cells are motile, have a mean cell diameter of $1.85 \mu \mathrm{m}$ and do not contain gas vesicles (Fig. 1). Around individual cells, slight slime production is visible. In phases of stationary growth, cells form microcolonies of irregular shape (Fig. 1). When growing with sulfide and thiosulfate as photosynthetic electron donors, the cells contain sulfur globules stored inside the cell (Figs 1 and 2a). Electron microscopy of thin sections revealed the presence of an intracellular membrane system of the vesicular type and a cell wall typical of Gram-negative bacteria (Fig. 2). The external layer of the cell wall exhibits a multilayered structure (Fig. 2b). 
Table 1. Morphological and physiological properties of strain $\mathrm{WS}^{\top}$ and related reference strains

Strains: 1, Thiorhodococcus mannitoliphagus sp. nov. WS ${ }^{\mathrm{T}}$ (data from this study); 2, Trc. minor ATCC 700259 ${ }^{\mathrm{T}}$ (Guyoneaud et al., 1997); 3 , 'Trc. drewsii' DSM 15006 (Zaar et al., 2003); 4, Thiocystis violacea DSM 207 (unless indicated, data from Zaar et al., 2003). ND, No data available; $\mathrm{V}$, variable (strain dependent); +++ , outstanding increase in growth to nearly $300 \%$ of control; ++ , increase in growth to $>200 \%$ of control; + , increase in growth to $150-200 \%$ of control; $(+)$, increase in growth to < $150 \%$ of control; - , no utilization (growth similar to control); (i), decrease in growth of up to $50 \%$ compared with control; i, decrease in growth of $>50 \%$ compared with control. The following substrates (final concentration in $\mathrm{mM}$ in parentheses) were tested but were not used by strain $\mathrm{WS}^{\mathrm{T}}$ : citrate $(5)$, benzoate (2), sucrose (5), trehalose (5), glutamate (5), aspartate (5), gluconate (5), glycine betaine (5). Substrates tested as i are: caprylate (2), palmitate (2), cysteine (2), methionine (2). Substrates tested as (i) are: tartrate (5), butanol (5), glycerol (5), thioglycolate (2). All strains have spherical cells with flagellar motility and lack gas vesicles. All strains use sulfide, sulfur and thiosulfate as photosynthetic electron donors and photoassimilate acetate, propionate, pyruvate and fumarate as organic substrates.

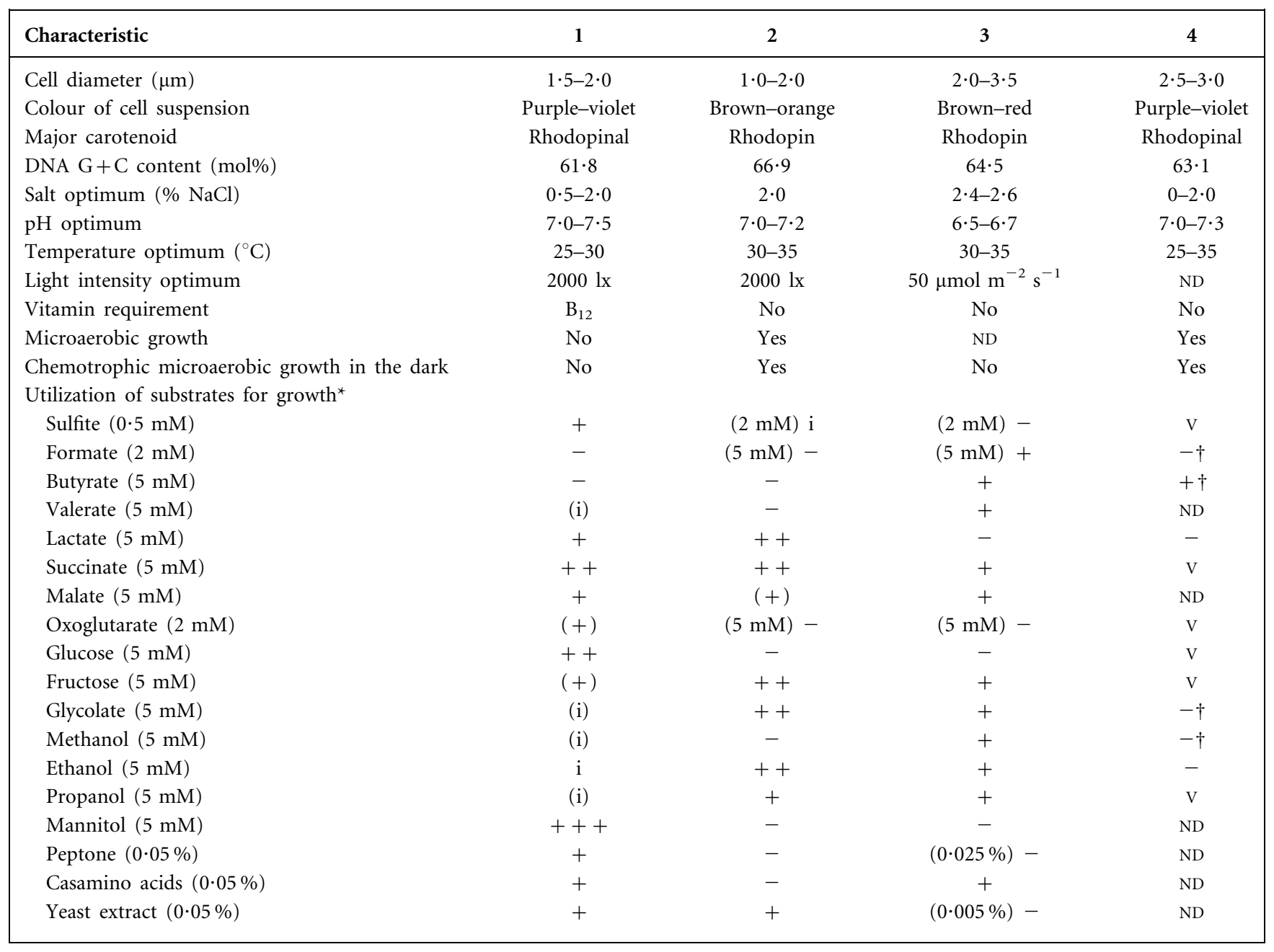

${ }^{\star}$ Tested at the concentration shown unless indicated.

$\dagger$ Data from Imhoff (2001).

Cell suspensions of liquid cultures of strain $\mathrm{WS}^{\mathrm{T}}$ exhibit a purple-violet colour. The absorption spectrum showed maxima at 888, 856, 805, 591, 528, 493, 458 and $375 \mathrm{~nm}$ (Fig. 3), which indicates the presence of bacteriochlorophyll $a$ and carotenoids of the rhodopinal series.

Growth of strain $\mathrm{WS}^{\mathrm{T}}$ was decreased strongly below $\mathrm{pH} 7 \cdot 0$ and decreased slightly above $\mathrm{pH} 7 \cdot 5$ (Fig. 4a). The $\mathrm{pH}$ optimum is $7 \cdot 0-7 \cdot 5$ and the $\mathrm{pH}$ tolerance is between $7 \cdot 0$ and $8 \cdot 5$. Growth experiments concerning the salt concentration revealed slightly decreased growth of strain $\mathrm{WS}^{\mathrm{T}}$ at concentrations higher then $2 \% \mathrm{NaCl}$ and in strongly decreased growth with more than $3 \% \mathrm{NaCl}$. No growth occurred at $5 \% \mathrm{NaCl}$. Without salt, strain $\mathrm{WS}^{\mathrm{T}}$ exhibited no growth, but growth increased very steeply at $0.1 \%$ $\mathrm{NaCl}$ (Fig. 4b). Thus, the salt optimum of strain $\mathrm{WS}^{\mathrm{T}}$ lies between 0.5 and $2.0 \%$, while the tolerance range can be defined as $0 \cdot 1-3 \cdot 0 \%$. Growth optima for temperature 


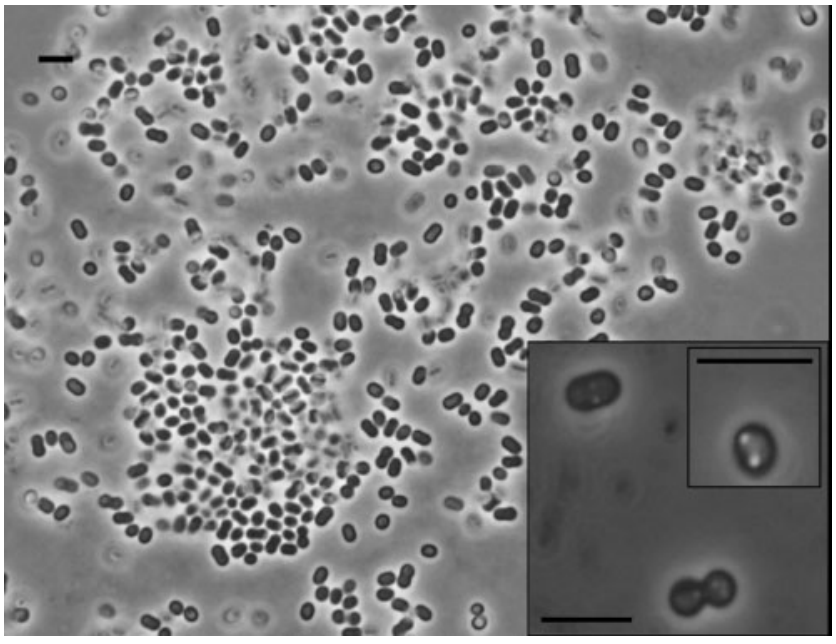

Fig. 1. Phase-contrast photomicrographs showing the morphology of strain $\mathrm{WS}^{\top}$. Cells were grown photolithoautotrophically with sulfide and thiosulfate under optimal conditions. Some cells show intracellular sulfur globules. Bars, $5 \mu \mathrm{m}$.

and light were found at $25-30{ }^{\circ} \mathrm{C}$ and $2000 \mathrm{~lx}(42 \mu \mathrm{mol}$ quanta $\mathrm{s}^{-1} \mathrm{~m}^{-2}$ ).

For photolithoautotrophic growth of strain $\mathrm{WS}^{\mathrm{T}}$ under anoxic conditions in the light, sulfide, thiosulfate, sulfite and elemental sulfur were used as electron donors. Globules of elemental sulfur were formed during oxidation of sulfide and thiosulfate and stored transiently inside the cells. In the presence of carbonate and a reduced sulfur source (sulfide or thiosulfate or both), a number of organic substrates were photoassimilated. Strain $\mathrm{WS}^{\mathrm{T}}$ exhibited photoassimilation of acetate, lactate, pyruvate, malate, peptone, Casamino acids and yeast extract, propionate, succinate, fumarate and glucose, while the utilization of mannitol resulted in an outstanding increase of growth. Oxoglutarate and fructose increased cell yields only slightly. No growth of strain $\mathrm{WS}^{\mathrm{T}}$ was observed either under microaerobic conditions in the light or chemotrophically in the dark. Thus, the bacterium is strictly anaerobic and obligately phototrophic. Vitamin $\mathrm{B}_{12}$ is a required growth factor.

Analysis of the 16S rRNA gene sequence was used to reveal the phylogenetic placement of strain $\mathrm{WS}^{\mathrm{T}}$ among other species of the family Chromatiaceae. The data clearly show that strain $\mathrm{WS}^{\mathrm{T}}$ belongs to the genus Thiorhodococcus (Fig. 5). The highest sequence similarities found were to Trc. minor CE2203 $3^{\mathrm{T}}(97 \cdot 3 \%)$ and 'Thiorhodococcus drewsii' DSM $15006(96 \cdot 1 \%)$. The base composition of purified DNA of strain $\mathrm{WS}^{\mathrm{T}}$ is $61 \cdot 8 \mathrm{~mol} \% \mathrm{G}+\mathrm{C}$.

Analysis of genetic relationships on the basis of $16 \mathrm{~S}$ rRNA gene sequences, enabled by the establishment of sequencing techniques, demonstrated the ambiguous impact of morphological and physiological properties for the differentiation of bacterial species (Imhoff et al., 1998b).

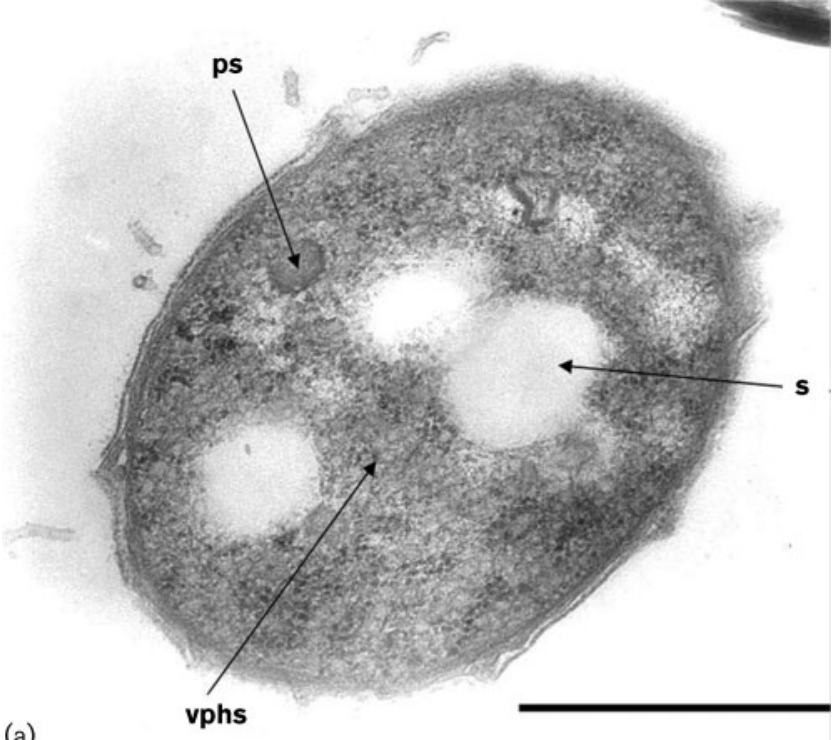

(a)

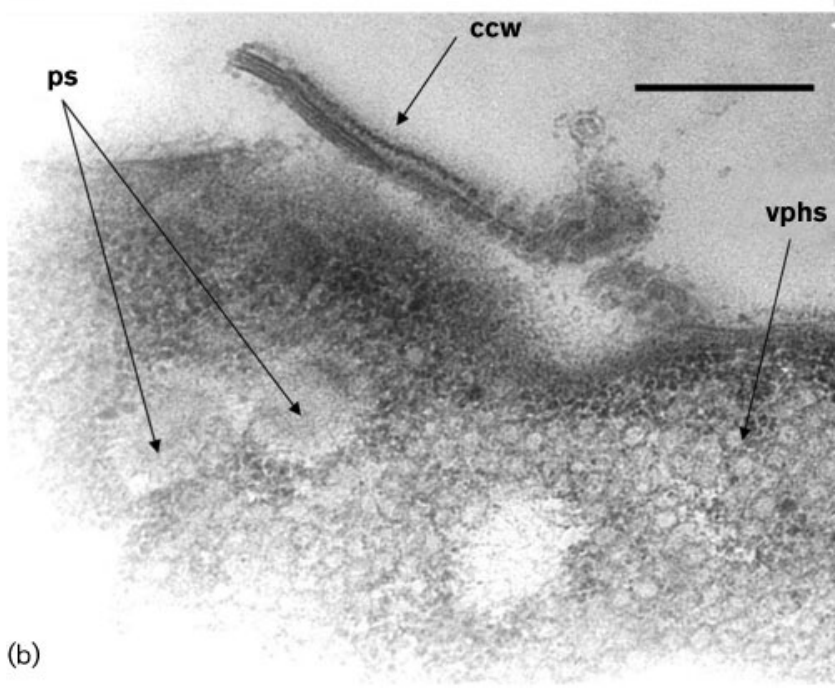

Fig. 2. Electron photomicrographs of ultrathin sections of cells of strain $W^{\top}$ grown photoautotrophically. Vesicular internal membranes have developed within the bacteria. (a) Whole-cell ultrathin section showing sulfur globules. (b) Detailed ultrathin section of a cell fragment showing photosynthetic membrane system of the vesicular type and the multilayered structure of the cell wall. Abbreviations: ps, polysaccharides; vphs, vesicular type of photosynthetic structures; s, sulfur inclusions; ccw, outer layer of cell wall. Bars, $1 \mu \mathrm{m}$.

Consequently, the taxonomy of phototrophic bacteria has been carefully revised by combining information from gene sequences and selected phenotypic characteristics as diagnostic properties (Imhoff \& Süling, 1996; Imhoff et al., 1998a, b; Imhoff, 2003; Guyoneaud et al., 1998). By combining genetic and phenotypic features, clear differentiation of the novel bacterial species described in this communication from closely related species was achieved. Morphological properties such as cell shape and size, the absence of 


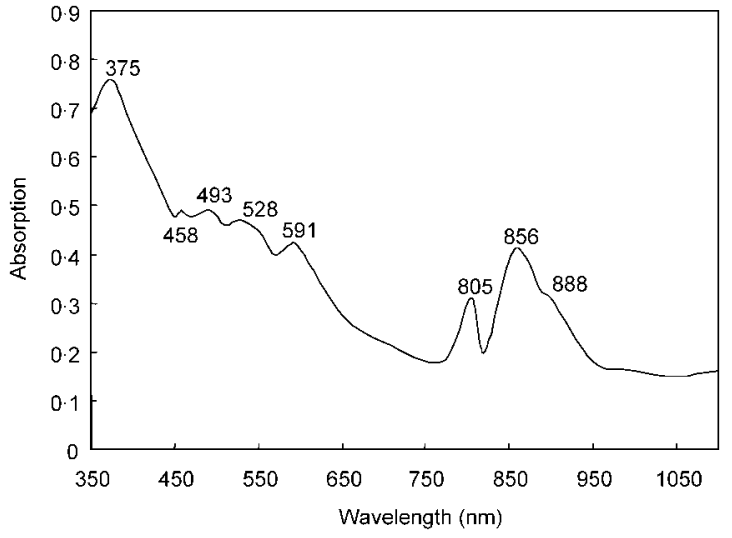

Fig. 3. Absorption spectrum of living cells of strain $\mathrm{WS}^{\top}$ suspended in $50 \%$ glycerol.

gas vesicles and motility of the new isolate are in accordance with properties of the genus Thiorhodococcus as well as Thiocystis. Genetically, strain $\mathrm{WS}^{\mathrm{T}}$ is affiliated to the genus Thiorhodococcus. Experimental studies revealed significant
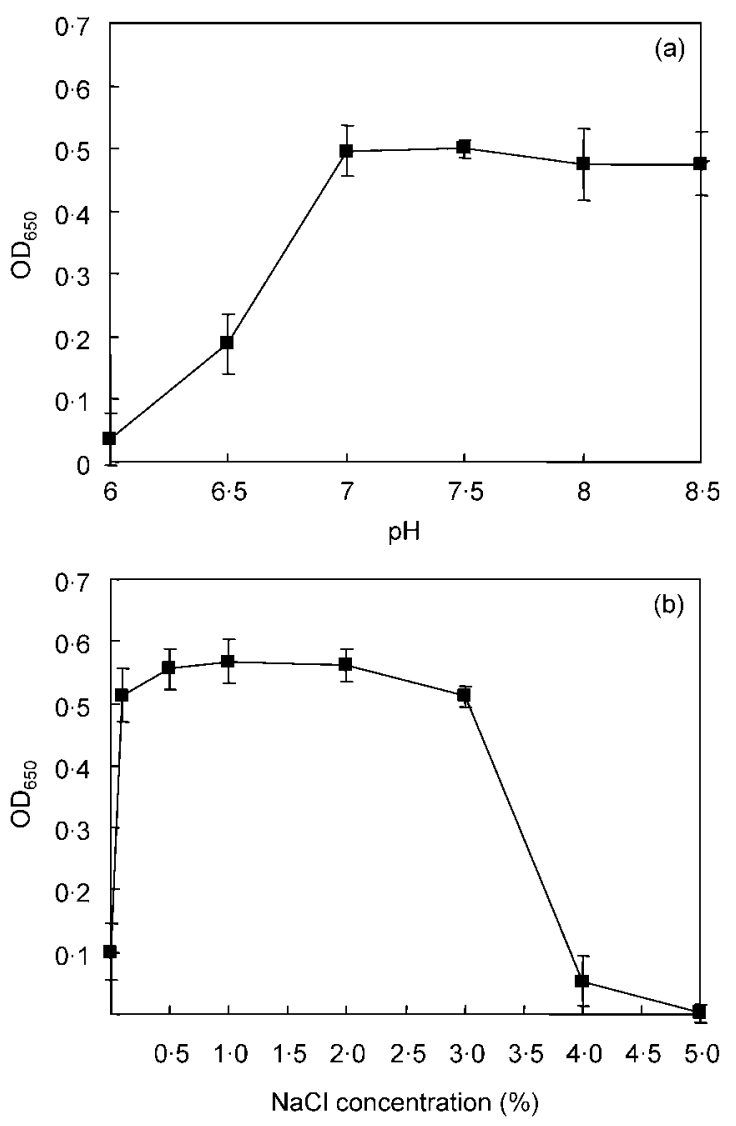

Fig. 4. Influence of $\mathrm{pH}$ (a) and salt concentration (b) on growth of strain $\mathrm{WS}^{\top}$. Experiments to determine the effect of salt concentration were performed at optimal $\mathrm{pH}$. phenotypic differences from related Thiorhodococcus species (Table 1) as well as clear separation by $16 \mathrm{~S}$ rRNA gene sequence similarities from both $\operatorname{Trc}$. minor $(97 \cdot 3 \%$ similarity to the type strain) and ' $\operatorname{Trc}$. drewsii' (96.1\% similarity to the proposed type strain). Both Trc. minor and 'Trc. drewsii' contain spirilloxanthin as main carotenoid, while rhodopinal is the major component in strain $\mathrm{WS}^{\mathrm{T}}$. With respect to physiological properties, slight differences can be seen in $\mathrm{pH}$ and salt requirements. Compared with other species of this genus, the salt optimum of strain $\mathrm{WS}^{\mathrm{T}}$ is shifted slightly towards lower salt concentrations. This property is probably connected with the isolation of the novel strain from microbial mats developing in brackish, shallow supralittoral zones of the White Sea. On the other hand, the $\mathrm{pH}$ requirement of strain $\mathrm{WS}^{\mathrm{T}}$ exhibits an affinity to slightly more alkaline conditions ( $\mathrm{pH} 7 \cdot 5$ and $8 \cdot 5$ ). In terms of substrate utilization, again similarities and differences can be seen. Common to all members of the genus Thiorhodococcus is the utilization of acetate, pyruvate, succinate, malate and fumarate as carbon substrates. Glucose is used exclusively by strain $\mathrm{WS}^{\mathrm{T}}$. An outstanding and unique characteristic of strain WS ${ }^{\mathrm{T}}$ is good growth with mannitol.

\section{Description of Thiorhodococcus mannitoliphagus sp. nov.}

Thiorhodococcus mannitoliphagus (mann.i.to'li.pha'gus. N.L. n. mannitolum mannitol; Gr. v. phagein to eat; N.L. masc. adj. mannitoliphagus consuming mannitol).

Cells are coccoid with mean cell diameter of $1.85 \mu \mathrm{m}$. During binary fission, diplococci are formed. Cells are Gram-negative, motile by flagella and do not contain gas vesicles. In the stationary growth phase, cells form irregular microcolonies. Colour of cell suspensions is purpleviolet. Photosynthetic membrane system is of the vesicular type. Photosynthetic pigments are bacteriochlorophyll $a$ and carotenoids of the rhodopinal series. Phototrophic growth occurs under anoxic conditions in the light. No growth occurs under microaerobic conditions in the light or under chemotrophic conditions in the dark. Vitamin $\mathrm{B}_{12}$ is required as a growth factor. Electron donors used for photolithoautotrophic growth are sulfide, thiosulfate, sulfite and elemental sulfur. Globules of elemental sulfur, which are formed during photolithoautotrophic growth with sulfide and thiosulfate, are stored transiently inside the cells and are oxidized further to sulfate. In the presence of carbonate and a reduced sulfur source (sulfide and/or thiosulfate), oxoglutarate, fructose, acetate, lactate, pyruvate, malate, peptone, Casamino acids, yeast extract, propionate, succinate, fumarate, glucose and mannitol are photoassimilated. The utilization of mannitol results in an outstanding increase in growth. Conditions for optimal growth are $25-30{ }^{\circ} \mathrm{C}, 2000 \mathrm{~lx}\left(42 \mu \mathrm{mol} \mathrm{m}^{-2} \mathrm{~s}^{-1}\right)$, pH $7 \cdot 0-7 \cdot 5$ and concentrations of $0 \cdot 5-2 \% \mathrm{NaCl}$. The DNA base composition of the type strain is $61 \cdot 8 \mathrm{~mol} \%$ $\mathrm{G}+\mathrm{C}$. 


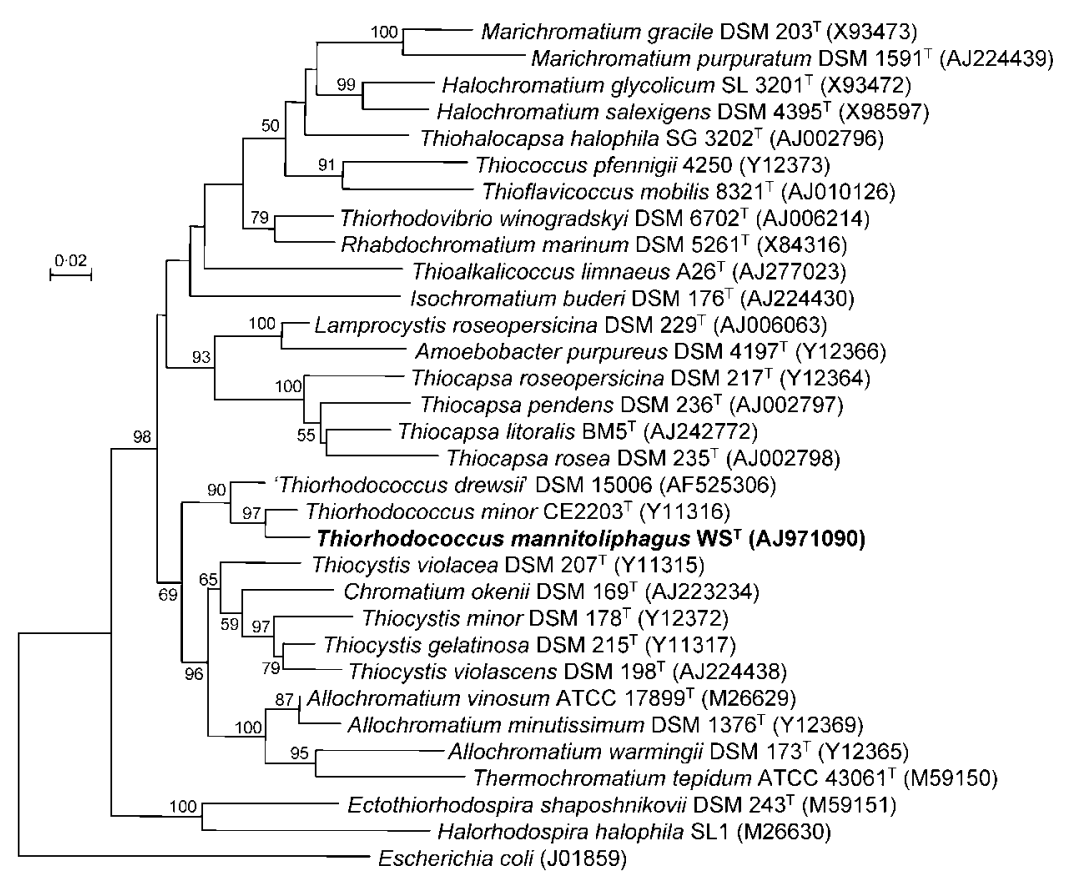

Fig. 5. Phylogenetic tree based on $16 \mathrm{~S}$ rRNA gene sequences illustrating the relationship of Thiorhodococcus mannitoliphagus $\mathrm{WS}^{\top}$ and related purple sulfur bacteria. Calculations were done as described in the text. Bar, 0.02 substitutions per position.
The type strain, $\mathrm{WS}^{\mathrm{T}}$ (=ATCC BAA- $1228^{\mathrm{T}}=\mathrm{VKM}$ B$2393^{\mathrm{T}}$ ), was isolated from microbial mat communities of an estuary of the White Sea.

\section{Acknowledgements}

This work was supported by grant no. 02-04-48196 from the Russian Foundation for Basic Research N 04-04-48602, Program RAS 'Molecular and Cell Biology' and Program RAS 'Origin and evolution of life on the Earth'. We thank J. Süling and F. Lappe for their supporting work concerning genetic analysis and furthermore K. Bischof (Institute for Polar Ecology, Kiel) for radiation measurements.

\section{References}

Bryantseva, I. A., Gorlenko, V. M., Kompantseva, E. I. \& Imhoff, J. F. (2000). Thioalkalicoccus limnaeus gen. nov., sp. nov., a new alkaliphilic purple sulfur bacterium with bacteriochlorophyll $b$. Int J Syst Evol Microbiol 50, 2157-2163.

Felsenstein, J. (2004). PHYLIP - Phylogeny Inference Package, version 3.6. Distributed by the author. University of Washington, Seattle, USA.

Gorlenko, V. M., Puchkova, N. N. \& Demchev, V. V. (1985). Photosynthetic microorganisms of supralittoral bath of White Sea (Rus.). Dokl Biol Sci 5, 66-72 (in Russian).

Guyoneaud, R., Matheron, R., Liesack, W., Imhoff, J. F. \& Caumette, P. (1997). Thiorhodococcus minus, gen. nov., sp. nov., a new purple sulfur bacterium isolated from coastal lagoon sediments. Arch Microbiol 168, 16-23.

Guyoneaud, R., Süling, J., Petri, R., Matheron, R., Caumette, P., Pfennig, N. \& Imhoff, J. F. (1998). Taxonomic rearrangements of the genera Thiocapsa and Amoebobacter on the basis of 16S rDNA sequence analyses, and description of Thiolamprovum gen. nov. Int J Syst Bacteriol 48, 957-964.
Imhoff, J. F. (1984). Reassignment of the genus Ectothiorhodospira Pelsh 1936 to a new family Ectothiorhodospiraceae fam. nov., and emended description of the Chromatiaceae Bavendamm 1924. Int $J$ Syst Bacteriol 34, 338-339.

Imhoff, J. F. (1992). The family Ectothiorhodospiraceae. In The Prokaryotes. A Handbook on the Biology of Bacteria. Ecophysiology, Isolation, Identification, Applications, 2nd edn, pp. 3222-3229. Edited by A. Balows, H. G. Trüper, M. Dworkin, W. Harder \& K. H. Schleifer. New York: Springer.

Imhoff, J. F. (2001). The anoxygenic phototrophic purple bacteria. In Bergey's Manual of Systematic Bacteriology, 2nd edn, vol. 1, pp. 631-637. Edited by D. R. Boone, R. W. Castenholz \& G. M. Garrity. New York: Springer.

Imhoff, J. F. (2003). Phylogenetic taxonomy of the family Chlorobiaceae on the basis of $16 \mathrm{~S}$ rRNA and fmo (Fenna-MatthewsOlson protein) gene sequences. Int J Syst Evol Microbiol 53, 941-951.

Imhoff, J. F. \& Caumette, P. (2004). Recommended standards for the description of new species of anoxygenic phototrophic bacteria. Int $J$ Syst Evol Microbiol 54, 1415-1421.

Imhoff, J. F. \& Pfennig, N. (2001). Thioflavicoccus mobilis gen. nov., sp. nov., a novel purple sulfur bacterium with bacteriochlorophyll $b$. Int J Syst Evol Microbiol 51, 105-110.

Imhoff, J. F. \& Süling, J. (1996). The phylogenetic relationship among Ectothiorhodospiraceae. A re-evaluation of their taxonomy on the basis of rDNA analyses. Arch Microbiol 165, 106-113.

Imhoff, J. F., Petri, R. \& Süling, J. (1998a). Reclassification of species of the spiral-shaped phototrophic purple non-sulfur bacteria of the $\alpha$-Proteobacteria: description of the new genera Phaeospirillum gen. nov., Rhodovibrio gen. nov., Rhodothalassium gen. nov. and Roseospira gen. nov. as well as transfer of Rhodospirillum fulvum to Phaeospirillum fulvum comb. nov., of Rhodospirillum molischianum to Phaeospirillum molischianum comb. nov., of Rhodospirillum salinarum to Rhodovibrio salinarum comb. nov., of Rhodospirillum sodomense to Rhodovibrio sodomensis comb. nov., of Rhodospirillum salexigens to Rhodothalassium salexigens comb. nov., and of 
Rhodospirillum mediosalinum to Roseospira mediosalina comb. nov. Int J Syst Bacteriol 48, 793-798.

Imhoff, J. F., Süling, J. \& Petri, R. (1998b). Phylogenetic relationship among the Chromatiaceae, their taxonomic reclassification and description of the new genera Allochromatium, Halochromatium, Isochromatium, Marichromatium, Thiococcus, Thiohalocapsa and Thermochromatium. Int J Syst Bacteriol 48, 1129-1143.

Marmur, J. (1961). A procedure for the isolation of DNA from microorganisms. J Mol Biol 3, 208-218.

Owen, R. J., Hill, L. R. \& Lapage, S. P. (1969). Determination of DNA base compositions from melting profiles in dilute buffers. Biopolymers 7, 503-516.

Pfennig, N. \& Trüper, H. G. (1974). The phototrophic bacteria. In Bergey's Manual of Determinative Bacteriology, 8th edn, pp. 24-75. Edited by R. E. Buchanan \& N. E. Gibbons. Baltimore: Williams \& Wilkins.

Pfennig, N. \& Trüper, H. G. (1992). The family Chromatiaceae. In The Prokaryotes. A Handbook on the Biology of Bacteria. Ecophysiology, Isolation, Identification, Applications, 2nd edn, pp. 3200-3221. Edited by A. Balows, H. G. Trüper, M. Dworkin, W. Harder \& K. H. Schleifer. New York: Springer.

Puchkova, N. N., Imhoff, J. F. \& Gorlenko, V. M. (2000). Thiocapsa litoralis sp. nov., a new purple sulfur bacterium from microbial mats from the White Sea. Int J Syst Evol Microbiol 50, 1441-1447.
Ryter, A. \& Kellenberger, E. (1958). Embedding in polyester for ultrathin sections. J Ultrastruct Res 2, 200-212.

Sanger, F., Nicklen, S. \& Coulson, A. R. (1977). DNA sequencing with chain-terminating inhibitors. Proc Natl Acad Sci U S A 74, 5463-5467.

Siefert, E. \& Pfennig, N. (1984). Convenient method to prepare neutral sulfide solution for cultivation of phototrophic sulfur bacteria. Arch Microbiol 139, 100-101.

Swindell, S. R. \& Plasterer, T. N. (1997). SEQMAN. Contig assembly. Methods Mol Biol 70, 75-89.

Thompson, J. D., Gibson, T. J., Plewniak, F., Jeanmougin, F. \& Higgins, D. G. (1997). The CLUSTAL_X windows interface: flexible strategies for multiple sequence alignment aided by quality analysis tools. Nucleic Acids Res 25, 4876-4882.

van Gemerden, H. \& Mas, J. (1995). Ecology of phototrophic sulfur bacteria. In Anoxygenic Photosynthetic Bacteria, pp. 49-85. Edited by R. E. Blankenship, M. T. Madigan \& C. E. Bauer. Dordrecht: Kluwer Academic.

Winogradsky, S. (1888). Zur Morphologie und Physiologie der Schwefelbakterien. In Beiträge zur Morphologie und Physiologie der Bakterien, Heft 1. Leipzig: Felix (in German).

Zaar, A., Fuchs, G., Golecki, J. R. \& Overmann, J. (2003). A new purple sulfur bacterium isolated from a littoral microbial mat, Thiorhodococcus drewsii sp. nov. Arch Microbiol 179, 174-183. 